\title{
Infection, vascularization, remodelling - are stem cells the answers for bone diseases of the jaws?
}

Jörg Handschel, Ulrich Meyer ${ }^{*}$

\begin{abstract}
Osteonecrosis after craniofacial radiation (ORN), osteomyelitis and bisphosphonates related necrosis of the jaw (BRONJ) are the predominant bone diseases in Cranio- and Maxillofacial surgery. Although various hypothesis for the pathophysiological mechanisms including infection, altered vascularisation or remodelling exist, the treatment is still a challenge for clinicians. As the classical pharmacological or surgical treatment protocols have only limited success, stem cells might be a promising treatment option, indicated by recently published data.
\end{abstract}

In maxillofacial surgery clinicians face three diseases of the jaws predominantly: osteonecrosis after craniofacial radiation (ORN), osteomyelitis and bisphosphonates related necrosis of the jaw (BRONJ). Numerous reports exist suggesting various pathological mechanisms and treatment modalities for these diseases [1,2]. Although these publications elucidate the prevalence, risk factors and treatment strategies, they have provided limited data on details of the underlying pathophysiology, especially differences in the three above mentioned diseases. The local or total immunsupressive therapy of many patients (e.g. cancer patients) and the universal presence of hundreds of microorganisms in the oral cavity provide a perfect environment for chronic infections like osteomyelitis. It is unclear if this contributes to BROMJ too. Currently, most evidence exist that the necrotic tissue becomes infected as opposed to the infected tissue becomes necrotic [3]. Regarding the effects on the immune system inconsistent data are reported in the literature. On the one hand bisphosphonates inhibit $\mathrm{T}$ lymphocyte activation and proliferation and suppress monocytes production of various pro-inflammatory cytokines [4]. On the other hand they increase the production of pro-inflammatory cytokines by lymphocytes [5]. Whereas the most widely accepted theory to explain the cause of ORN is the theory of hypoxia, radio-induced hypovascularity and hypocellularity $[6,7]$ there is no evidence that the necrotic regions in BRONJ have reduced vasculature or blood supply. However, antiangiogenic effects of bisphosphonates have been reported by other

\footnotetext{
* Correspondence: praxis@mkg-muenster.de

Department for Cranio- and Maxillofacial Surgery, Heinrich-Heine-University, Moorenstr. 5, D-40225 Düsseldorf, Germany
}

authors [8]. Remoddeling suppression is an other causative factor held responsible for BRONJ despite the fact that there are no published data in humans showing the effects of bisphosphonates on jaw remodeling [2]. Taken together there are only very few studies (e.g. animal studies) clarifying the basic pathophysiological mechanisms of these bone diseases. Very recently, a new treatment modality was introduced elucidating one possible causative factor for BRONJ. Kikuiri and coworkers infused mesenchymal stem cells in BRONJ-like mice. The stem cells modulated the immune system, prevent and cure BRONJ-like disease [9]. Since it is known, that stem cells can induce ectopic bone formation [10] as well as angiogenesis [11], stem cells might be a future treatment option for the above mentioned bone diseases. Particularly, with respect to the full capacity of various stem cell lines [12,13], these cells might become a promising tool for clinicians.

Received: 3 January 2011 Accepted: 18 February 2011 Published: 18 February 2011

\section{References}

1. Allen MR, Burr DB: The pathogenesis of bisphosphonate-related osteonecrosis of the jaw: so many hypotheses, so few data. J Oral Maxillofac Surg 2009, 67:61-70.

2. Allen MR: Bisphosphonates and osteonecrosis of the jaw: moving from the bedside to the bench. Cells Tissues Organs 2009, 189:289-294.

3. Yarom N, Yahalom R, Shoshani Y, Hamed W, Regev E, Elad S: Osteonecrosis of the jaw induced by orally administered bisphosphonates: incidence, clinical features, predisposing factors and treatment outcome. Osteoporos Int 2007, 18:1363-1370.

4. Sansoni P, Passeri G, Fagnoni F, Mohagheghpour N, Snelli G, Brianti V, Engleman EG: Inhibition of antigen-presenting cell function by alendronate in vitro. J Bone Miner Res 1995, 10:1719-1725.
C Biomed Central

(c) 2011 Handschel and Meyer; licensee BioMed Central Ltd. This is an Open Access article distributed under the terms of the Creative Commons Attribution License (http://creativecommons.org/licenses/by/2.0), which permits unrestricted use, distribution, and reproduction in any medium, provided the original work is properly cited. 
5. Coxon FP, Thompson K, Rogers MJ: Recent advances in understanding the mechanism of action of bisphosphonates. Curr Opin Pharmacol 2006, 6:307-312.

6. Chrcanovic BR, Reher P, Sousa AA, Harris M: Osteoradionecrosis of the jaws-a current overview-part 1: Physiopathology and risk and predisposing factors. Oral Maxillofac Surg 2010, 14:3-16.

7. Prott FJ, Handschel J, Micke O, Sunderkotter C, Meyer U, Piffko J: Long-term alterations of oral mucosa in radiotherapy patients. Int I Radiat Oncol Biol Phys 2002, 54:203-210.

8. Wood J, Bonjean K, Ruetz S, Bellahcene A, Devy L, Foidart JM, Castronovo V Green JR: Novel antiangiogenic effects of the bisphosphonate compound zoledronic acid. J Pharmacol Exp Ther 2002, 302:1055-1061.

9. Kikuiri T, Kim I, Yamaza T, Akiyama K, Zhang Q, Li Y, Chen C, Chen W, Wang S, Le AD, Shi S: Cell-based immunotherapy with mesenchymal stem cells cures bisphosphonate-related osteonecrosis of the jaw-like disease in mice. J Bone Miner Res 2010, 25:1668-1679.

10. Handschel J, Naujoks C, Langenbach F, Berr K, Depprich RA, Ommerborn MA, Kubler NR, Brinkmann M, Kogler G, Meyer U: Comparison of ectopic bone formation of embryonic stem cells and cord blood stem cells in vivo. Tissue Eng Part A 2010, 16:2475-2483.

11. Luo JZ, Xiong F, Al-Homsi AS, Roy T, Luo LG: Human BM stem cells initiate angiogenesis in human islets in vitro. Bone Marrow Transplant 2010

12. Meyer U, Meyer T, Handschel J, Wiesmann HP: Fundamentals of Tissue Engineering and Regenerative Medicine Berlin, Heidelberg: Springer-Verlag; 2009.

13. Handschel J, Berr K, Depprich RA, Kubler NR, Naujoks C, Wiesmann HP, Ommerborn MA, Meyer U: Induction of osteogenic markers in differentially treated cultures of embryonic stem cells. Head Face Med 2008, 4:10.

doi:10.1186/1746-160X-7-5

Cite this article as: Handschel and Meyer: Infection, vascularization remodelling - are stem cells the answers for bone diseases of the jaws? Head \& Face Medicine 2011 7:5.

\section{Submit your next manuscript to BioMed Central and take full advantage of:}

- Convenient online submission

- Thorough peer review

- No space constraints or color figure charges

- Immediate publication on acceptance

- Inclusion in PubMed, CAS, Scopus and Google Scholar

- Research which is freely available for redistribution

Submit your manuscript at www.biomedcentral.com/submit 